\title{
Growth Phase
}

National Cancer Institute

\section{Source}

National Cancer Institute. Growth Phase. NCI Thesaurus. Code C159261.

The morphologic architectural pattern in which the tumor cells spread. 